\title{
Comments to a publication of Stovba et al., 2020 "Geological structure and tectonic evolution of the Ukrainian sector of the Black Sea", Geophysical Journal, 2020, Vol. 42, № 5, P. 53-106
}

\author{
Ye. Korniyenko Sheremet, 2020 \\ University of Côte d'Azur, Nice, France
}

Received 25 December 2020

Considering such a large volume of seismic material that the authors have at their disposal and which is declared by the authors at the beginning of the publication, it was expected, based on the title of the paper of [Stovba et al., 2020], that it should shed light on the main issues in the geology and tectonics of this northern sector of the Black Sea. The authors in their attempts to present a consistent sets of structure and isopach maps of the offshore of the northern part of the Black Sea unfortunately presented the material which is not significantly revised from anything that went before, but summarizing mostly their own interpretation presented already earlier. In view that the stratigraphy in this area is largely inferred/extrapolated, the authors of the current publications should payed more attention to a previous work, including seismic interpretation recently published, and if they decided to neglect/ignore this previous contribution they should explain in details their methodology, to show how the extrapolation of the age of the seismic units took place and to point out on exact possible mistakes, admitted in previous studies. Since none of this was proposed in the article, then it (here I also express my subjective opinion) remains well-composed and consistent, but subjective in the absence of convincing arguments in favor of this model use.

In view of the above-mentioned bias, I will not touch upon your analytical work on the tectonic evolution of the Black Sea basin: there is an opinion that this analytical work is rather not finished, but should be continued taking into account the geological facts available for wide use in the mountain domains around the Black Sea basin, to form new arguments, based on these facts, about the development of each region to compose a final vision of the Black Sea tectonic evolution in the scale of plate tectonics.

My comments concern the works of [Sheremet et al., 2016a, b] cited in the text of the paper. The authors cite them sometimes inaccurately, sometimes twisting the meaning of the conclusions drawn, and sometimes completely speculatively and therefore form a somewhat distorted image of our publications. In addition [Stovba et al., 2020] could pay more attention to analytical studies of your colleagues (Institute of Geophysics of the National Academy of Science of Ukraine) intended to solve the same general tectonic problems in this area.

On page 61 You wrote: "One of main results of the fieldwork concerns the accurate definition of the age of 'Triassic-Middle Jurassic' siliciclastic sedimentary rocks mentioned above. A new study of microfauna in rock samples that were collected from many outcrops located in different parts of the Crimea Mountains showed that these rocks should be dated as not older than the Early Cretaceous.

... The fact that in the central and eastern parts of the Crimea Mountains the sediments of the Tavric Group were not deposited earlier than in the Early Cretaceous has been recently confirmed by paleontological data recently obtained by [Sheremet et al., 2016a,b].

It has to be precised that we have never 
"proved» that Tavric Group has a Cretaceous age. We indeed concluded that there are two flysh-like units, we cite: «the oldest unit is of Late Triassic-Middle Jurassic age and the other is of Early Cretaceous age» [Sheremet et al., 2016a]. In the mentioned paper we presented a structural map, where by a dashed zigzag line we marked the approximate location and type of contact (stratigraphic) between these flysch units of different ages. A zigzag line means that both flysches are deformed into folds. I would also draw your attention to an article that went unnoticed by you, but which is important for understanding the relationship between flysch of different ages in the southern part of the Crimean Mountains [Oszczypko et al., 2017]. This work also supports the stratigraphic contact between two flyshes and, according to the cross-section constructed using data of new foraminifers dating of flysch rocks, both flysches are folded and deformed [Oszczypko et al., 2017].

Therefore, I address you to read more attentively the Discussion and the Conclusion section of [Sheremet et al., 2016a] where, in general terms, it is explained why we, like many other researchers, cannot accept your position about the $\sim$ Albian age of flysch everywhere in the Crimea Mountains, that is, to accept the model of the geological and tectonic settings presented on the map published by SPK-Geoservise team in 2013.

On page 85 You wrote: "The offshore zone, ... along the Crimea Peninsula and comprises the MCCF and Sorokin Trough, is characterised by severe deformations of the sedimentary cover.

... The absence of deep wells, except those drilled on the Subbotina structure ..., aggravates the correlation and stratification of seismic horizons. That is why the tectonic units mapped by previous regional seismic studies [Yanshin et al., 1977; Terekhov, 1979; Finetty et al., 1988; Terekhov, Shimkus, 1989; Meisner, Tugolesov, 2003; Sydorenko et al., 2016; Sheremet et al., 2016b] are not the same as those determined in the present study, which is more comprehensive and why tectonic reconstructions in this are a are still very rough".

With this I have the following comments:
The authors, which you have cited here, tried to interpolate the age of seismic horizons based on the same Subbotina well, which you also refer to. Unfortunately, not each publication devoted to the interpretation of seismic profiles in the Sorokin Trough gives a thorough analysis of how the ages of seismic units were defined in order to convince the reader in the correctness of their age determinations. Meanwhile, the work of [Sheremet et al., 2016 b] provides a fairly reasonable interpolation of the age of these horizons in Sorokin Trough. Additionally, [Sheremet et al., 2016 b], pointed out where the possible mistake of the age definition of the seismic units occurred previously, including the publications with your authorship.

The Fig. 8 (from [Sheremet et al., 2016b]) is exactly that fragment of the seismic line (SL7, see Fig. 2 from [Sheremet et al., 2016b] for the location) that is close to the Subbotin structure. Therefore, it allows interpolation (projection on this SL7) of the age of the seismic horizons in the Sorokin Trough from the seismic profile published in [Stovba et al., 2009], containing the Subbotina well, because of the intersection between them (between the SL7 from [Sheremet et al., 2016b] and the seismic profile from [Stovba et al., 2009]. Also, to note that for the seismic interpretation we used the seismic lines of Western Geophysical (1994), which, as you noticed, are of good quality.

Here we extract the fragment of the text from [Sheremet et al., 2016b], p. 95, section 5.2 «Paleocene-lower Eocene shortening», where we pointed out why in the previous studies the thickness of the younger units is overestimated: "... Our seismic stratigraphy is correlated with the Subbotina-403 well located within the continuation of the Sorokin Trough. In the well, the Maikopian is $2000 \mathrm{~m}$ thick ( 1.9 stwt) up to a depth of $2700 \mathrm{~m}$ ( 2.7 stwt) (Fig. 3). Following the Maikopian unit from the well [Stovba et al., 2009; Gozhik et al., 2010, Vakarchuk et al., 2016] utilizing the SL 7 (seismic line 7) (Figs. $2,7,8 \mathrm{C}$ ), it is only 0.1 to 0.3 stwt thick and its base reaches a maximum depth of $\sim 5$ stwt in the distal part of the Sorokin trough (Figs. 4 and 5). The sediments in the Sorokin Trough, 
interpreted by [Nikishin et al., 2015a,b] as Maikopian, reach a 6 stwt depth implying the overestimation of its thickness compared to the well data. Interpreted Maikopian unit in the Sorokin Trough, according to [Nikishin et al., 2015a,b, c], includes a significant part of Paleocene and Eocene deposits. The age of the flexural deformation is therefore older than suggested».

We also, provide here the fragment of the paper where we point out to a relevance of our results identifying the Paleocene horizon in the Sorokin trough (p. 88 from [Sheremet et al., 2016b]): "... We therefore suggest the Paleocene age for the Unit UG. This interpretation found the support in the isobaths map of Paleocene distribution in the Sorokin Trough [Tari et al., 2011]. On this map the top of the Paleocene structures are at depth $\sim 4000$-4300 $m$ that approximately corresponds to $\sim 4-4,3$ stwt, taking into account the mean velocity of seismic waves in the sediments $\left(2000 \mathrm{~m} \cdot \mathrm{s}^{-1}\right)$ ».

On p. 97 of [Sheremet et al., 2016 b] we also noted that «The stratigraphy we constrained does not contradict with the one, recently published for the entire Black Sea [Nikishin et al., 2015a,b,c] and two models fit since the Miocene».

Taking aforementioned into account, the stratigraphy you established for the Sorokin Trough in your paper, could be questioned, until you present a thorough and argumentative explanation of the accuracy of determining the age of seismic units and horizons in the off-shore the Crimean Mountains.

The same comment applies to p. 87 [Stovba et al., 2020], where you wrote that «Previous seismic studies have overestimated the thickness of the Paleocene-Eocene [Sheremet et al., 2016b] and/or Oligocene-Lower Miocene [Kazancev, 1982; Tugolesov et al., 1985; Finetty et al., 1988; Afanasenkov et al., 2007; Nikishin et al., 2015a, b; Sydorenko et al., 2016] sequences in the Sorokin Trough». To our opinion, you should have presented the strong arguments why and where those studies were mistaken.

On page 86 You wrote: "In addition, Sheremet et al. [2016b] did not note any evidence of a Cretaceous extensional regime in the Sorokin Trough and surrounding tectonic units, although they agree that Cretaceous rifting is the main mechanism of the formation of the EBSB and WBSB. However, evidence of Cretaceous rift processes has been widely recognised in the Crimea Mountains and Kerch Peninsula [Robinson, Kerusov, 1997; Nikishin et al., 2001, 2017; Hippolyte et al., 2018; Stovba et al., 2013, 2017 $a, b]$ and to the south of the Crimea shore line within the MCCF, Sorokin Trough, Tetyaev High and Shatskiy High [Stovba, Khriachtchevskaia, 2011; Stovba et al., 2013, 2017a,b]. Sydorenko et al. [2016] also suggested that like the whole Black Sea region the Sorokin Trough was probably affected by the Cretaceous and/or older rift processes".

In this place, you clearly pulled words out of context and twisted the meaning of the conclusions inside out, forming a totally unreasonable, wrong impression about the results of the study done by [Sheremet et al., 2016b]. To dispel the myth that [Sheremet et al., 2016b] have doubts about rifting in the Cretaceous, I will give here the full context from the paper [Sheremet et al., 2016b]: «The $N E-S W$ trending normal faults observed in this study occurred in the acoustic basement, only beneath and slightly in front of the tectonic wedge. Moreover, their offset is limited $(<0.3$ stwt) compared to major normal faults $(>1.5$ stwt) in the Eastern BS basin [Nikishin et al., $2015 a, b]$ related to Cretaceous BS opening ...». As you can see, we did not deny the Cretaceous extension, but talking about the local normal faults beneath the Cenozoic sediments in the Sorokin Trough.

... «We interpret them as those related to an extensional deformation initiated in the peripheral bulge [Tavani et al., 2015], resulting from the flexuring of the foreland basin below the tectonic wedge ..., the normal faults identified in this study should be in connection with subsequent compressional stage that postdates the opening of the Eastern BS, which occurred mostly during the Cretaceous, as in the Western BS [Görür, 1988;Okay et al., 1994, Nikishin et al., 2003, 2015a,b; Stephenson, Schellart, 2010; Sosson et al., 2016]. The Cretaceous extension offshore is clearly visible but at the boundaries of the Eastern BS [Nikishin et al., 2015a,b,c]». 
Thus, we would ask you to be more scrupulous when citing our publications.

On page 88 You wrote: "Sheremet et al. [2016b] interpreted some local folds as mud diapirs formed on inherited compressional structures on the southern flank of the Sorokin Trough and even above the Tetyaev High. Meanwhile, other studies showed that the most - if not all — folds are asymmetric and structurally complicated by reverse faults. The folds originated and evolved mainly in response to Cenozoic shortening of the Sorokin Trough and simultaneous ductile and brittle deformations in its sedimentary cover without any significant influence of mud diapirism [Terekhov, 1988; Terekhov, Shimkus, 1989; Ismagilov et al., 2002].

Again, I don't know, where those interpretations are coming from? Our study presented in [Sheremet et al., 2016b] is devoted to analysis of seismic lines in the Sorokin Trough. Because the mud volcano soccurred in the Sorokin Trough, they were touched mainly regarding the timing of triggering their activity. Only three phrases regarding mud volcanoes are written in this our paper, including two of them on p. 93 of [Sheremet et al., 2016b]. Nothing was said that we interpret some local folds as mud volcanism, more than this, we clearly stay on the opinion that mud volcanoes use thrust faults as conduits. Means that in view of their late appearance they cannot be a reason, but they are the consequence of the compressional deformations. But we assume that such a citation of our publications by [Stovba et al., 2020], will refer to the inattention of the authors, rather than to their inability to understand the material of our paper.

On page 88 You wrote: "Sheremet et al. [2016b], however, on the basis of field based observations in Crimea, speculated that decollement levels lay within the Paleocene, Upper Triassic-Lower Jurassic (Tavric flysch) and Lower Cretaceous successions. "Speculated» in general means to build a theory/argument without the evidence/facts.

I would also to remind you, that what is saying about the decollement level in [Sheremet et al., 2016b] is a generalization/summary of a field observation from [Sheremet, 2016], and a summary of the results of seismic interpretation from [Sheremet et al., 2016b]. Following this, the deformations related to these decollement levels (in the Cretaceous and Triassic-Jurassic flysh-like deposits) are shown on photos: so, there are no speculation about them. Regarding the decollement within the Paleocene deposits, this argument was built regarding the age of seismic units defined/interpolated according to Subbotina well (how it was done was explained above). So, according to this detailed work, this argument is not a speculation.

So, if in [Stovba et al., 2020] you did not explain where [Sheremet et al., 2016b] were wrong and how you defined the age of seismic units within the Sorokin Trough, then, if you pointed out to some speculations, then leave it to a reader to decide where they are. We urge Stovba and co-authors [2020] to be more correct by citing our publications and to provide well-grounded arguments if you want the scientific community consider the tectonic structure and development of the northern Black Sea sector based on your model.

In regards to the rift formation "and characteristics of the lithosphere within the northern deep-water Black Sea, which suggests considerable crustal thinning", on $p .93$ You wrote: «Stovba and Stephenson [2019] suggested that this inconsistency can be explained by the imprint of one or more significant extensional tectonic phases affecting the Black Sea lithosphere prior to the Cretaceous and an influence of plate tectonics as far back as the Late Palaeozoic. Other previous studies and geodynamic models also considered impacts of active tectonic processes caused by preCretaceous plate tectonics on the evolution of the Black Sea. Indeed, Zonenshain and Le Pichon [1986] suggested that the opening of the Black Sea basin occurred in the Jurassic. Some evidence of extensional deformation that could have occurred within the Andrusov Ridge long before the end of the Cretaceous were described by Finetty et al. [1988]».

Because Stovba and Stephenson [2019] is an abstract to which you refer as a source of this ideas presented at the workshop in Batumi 
(AAPG, ERC, Georgia, 2019), we would like to pay your attention on another presentation of [Sheremet et al., 2019] devoted to the same problematic also, presented in Batumi. During this oral presentation we attempted to define two generations of faults the timing of formation of which predated the formation of the Black Sea (means that we could be mentioned here on mentioned p. 93, and on p. 64 in [Stovba, Stephenson, 2019] «Two major systems of Albian-Cenomanian generated rift

\section{References}

Korniyenko Sheremet, Ye. (2016). Thesis PhD: Analyse structurale (terre-mer) de l'Est de la Crimée: conséquences sur l'évolution tectonique de la marge nord de la Mer Noire orientale. Diss. Nice.

Oszczypko, N., Ślączka, A., Bubniak, I., Olszewska, B., \& Garecka, M. (2017). The position and age of flysch deposits in the Crimean Mountains (Southern Ukraine). Geological Quarterly,61(4),697-722. https://doi.org/10.7306/gq. 1359 .

Sheremet, Y., Sosson, M., Muller, C., Gintov, O., Murovskaya, A., \& Yegorova, T. (2016a). Keyproblems of stratigraphy in the Eastern Crimea Peninsula: some insights from new dating and structural data. In M. Sosson, R.A. Stephenson, \& S. A. Adamia (Eds.), Tectonic Evolution of the Eastern Black Sea and Caucasus (Vol. 428, pp. 265-305). Geol. Soc., London, Spec. Publ. http://doi.org/10.1144/SP428.14.

Sheremet, Y., Sosson, M., Ratzov, G., Sydorenko, G., Voitsitskiy, Z., Yegorova, T., Gintov, O., \& Murovskaya, A. (2016 b). An offshore-on land transect across the north-eastern Black Sea basin (Crimean margin): evidence of Paleocene to Pliocene two-stage compression. Tectonophysics, 688, 84-100. https://doi.org/10.1016/j.tecto.2016.09.015. faults trend roughly NEE-SWW and NW-SE within the studied part of the Black Sea». In the presentation of [Sheremet et al., 2019] we discussed the possible timing of their formation and their directions, and said that both systems of faults were reactivated during the Cretaceous rifting of the Black Sea. Regarding this, we inform you that the corresponding paper is going to be published soon, and we advise you to trace it out for the references in your future work.

Sheremet (Korniyenko), Y., Sosson, M., Stephenson, R., Murovskaya, A., Seghedi, A., Barrier, E., \& Blanpied, Ch. (2019). Northern Black Sea's regions: structural patterns and timing of deformations. AAPG GTW: Exploration and Production in the Black Sea, Caucasus, and Caspian Region, 18-19 September 2019, Batumi, Georgia.

Stovba, S.M., Khriachtchevskaia, O.I., \& Popadyuk, I.V. (2009). Hydrocarbon Bearing Area in the Eastern Part of the Ukrainian Black Sea. The Leading Edge, 29(9), 1042-1045. https:// doi.org/10.1190/1.3236373.

Stovba, S.M., Popadyuk, I.V., Fenota, P.O., \& Khriachtchevskaia, O.I. (2020). Geological structure and tectonic evolution of the Ukrainian sector of the Black Sea. Geofizicheskiy Zhurnal, 42(5), 53-106. https://doi.org/10.24028/ gzh.0203-3100.v42i5.2020.215072.

Stovba, S.M., \& Stephenson, R.A. (2019). Reappraisal of the main Black Sea rifting phase in the Cretaceous and implications for the pre-rift history of the Black Sea lithosphere. Abstracts of AAPG GTW: Exploration and Production in the Black Sea, Caucasus, and Caspian Region. Batumi, Georgia, 18-19 September $2019.7 \mathrm{p}$. 